(C) Inra/Elsevier, Paris

Original article

\title{
Effect of inoculation and substrate disinfection method on rooting and ectomycorrhiza formation of Douglas fir cuttings
}

\author{
Javier Parladéa*, Joan Pera ${ }^{a}$, Isabel F. Álvarez ${ }^{\mathrm{a}}$, Daniel Bouchard ${ }^{\mathrm{b}}$, \\ Benoît Généréc, François Le Tacon ${ }^{b}$ \\ "Departament de Patologia Vegetal, Ctra de Cabrils s/n, IRTA, 08348 Cabrils, Barcelona, Spain \\ ${ }^{b}$ Centre de recherches forestièrès de Nancy, Inra, 54280 Champenoux, France \\ cCemagref, Domaine des Barres, 45290 Nogent-sur-Vernisson, France
}

(Received 2 February 1998; accepted 11 May 1998)

\begin{abstract}
Ectomycorrhizal inoculation techniques were applied to Douglas fir (Pseudotsuga menziesii (Mirb) Franco) cuttings, during the rooting phase, to determine the effect of inoculation on rooting and mycorrhizal colonization. Two experiments were conducted: 1) an inoculation experiment, established at three different locations with the same treatments, to determine the effect of inoculation with Laccaria bicolor, Melanogaster ambiguus and Rhizopogon subareolatus; and 2) a local factorial experiment to determine the effect of fungal inoculation, substrate disinfection methods, and their possible interactions. At Peyrat-le-Château and Champenoux (France), there were no differences in rooting due to the inoculation treatment. At Cabrils (Spain), the cuttings inoculated with $L$. bicolor and $R$. subareolatus rooted significantly better than non-inoculated cuttings. Vegetative inoculum of $L$. bicolor and spores of $R$. subareolatus were effective in forming ectomycorrhizas in the three locations, whereas spores of $M$. ambiguus were effective only at Cabrils. Substrate disinfection with methyl bromide significantly decreased the percentage of rooted cuttings compared to steam-disinfected substrate. Methyl bromide application also lowered the percentage of mycorrhizal cuttings after inoculation with $L$. bicolor and $R$. subareolatus. The disinfection method did not alter significantly the colonization level among the mycorrhizal plants. (C) Inra/Elsevier, Paris.)
\end{abstract}

\section{Laccaria bicolor / Melanogaster ambiguus / Rhizopogon subareolatus / propagation / mycorrhiza}

Résumé - Effet de méthodes d'inoculation et de désinfection du substrat sur l'enracinement de boutures de douglas et sur la formation de mycorhizes. La mycorhization contrôlée de boutures de douglas (Pseudotsuga menziesii (Mirb) Franco) a été étudiée durant la phase d'enracinement, afin de mesurer son effet sur l'enracinement et sur l'état mycorhizien final des plants. Deux essais ont été suivis: 1) un essai commun à trois sites comparant l'effet de souches fongiques de Laccaria bicolor, Melanogaster ambiguus et Rhizopogon subareolatus, et 2) un essai factoriel local testant l'effet de l'inoculation, du mode de désinfection du substrat et leurs interactions. Contrairement à Peyrat-le-Château et à Champenoux où le taux d'enracinement n'a pas été modifié par les symbiotes inoculés, les boutures inoculées par $L$. bicolor and $R$. subareolatus se sont mieux enracinées que les témoins à Cabrils. Le mycélium de $L$. bicolor et les spores de $R$. subareolatus ont permis la formation de mycorhizes sur les trois sites, alors que les spores de $M$. ambiguus ne l'ont permis qu'à Cabrils. La désinfection du substrat au bromure de méthyle a réduit significativement le taux de boutures racinées par rapport à celle effectuée à la vapeur. L'application de bromure de méthyle a diminué également le taux de boutures mycorhizées, après inoculation par $L$. bicolor et $R$. subareolatus. En revanche, la méthode de désinfection n'a pas modifié significativement le taux de mycorhization des plants effectivement mycorhizés. (@) Inra/Elsevier, Paris.)

\section{Laccaria bicolor / Melanogaster ambiguus / Rhizopogon subareolatus / multiplication végétative / mycorhize}

\footnotetext{
* Correspondence and reprints

parlade@cabrils.irta.es
} 


\section{INTRODUCTION}

Vegetative propagation of forest trees is an alternative to the lack of seeds of high genetic value when a breeding programme has been concluded. Several species of forest trees can be propagated as rooted cuttings from selected mother plants [22]. The increasing availability of genetically improved Douglas fir (Pseudotsuga menziesii (Mirb) Franco) seed, its successful propagation from cuttings in North America [23], and its increasing importance as a reforestation species in Europe [17] make this species a good candidate to be propagated as rooted cuttings. Since this propagation method is more expensive than seedling production, the effort to improve the rooting process and the performance of the rooted cuttings in the nursery and after field transplantation is of great interest. The critical stages during cutting propagation are the rooting phase and the transplantation to nursery beds and to the field. Inoculation of Douglas fir seedlings with selected ectomycorrhizal fungi, in both containerized and bareroot nurseries, can increase survival and/or growth of the plants in the nursery phase [13] and when outplanted in the field in European trials $[1,2,9,15,27]$. On cuttings, the fungal inoculum is generally supplied when the rooted cuttings are transplanted in fumigated beds [10].

In this study, we inoculated directly during the rooting phase to determine the effect of inoculation on rooting and mycorrhizal colonization. Available inoculation techniques with ectomycorrhizal fungi used for containerized seedlings were applied and adapted to Douglas fir cuttings. Two experiments were designed: 1) an inoculation experiment, established at three different locations with the same treatments, to determine the effect of inoculation with Laccaria bicolor, Melanogaster ambiguus and Rhizopogon subareolatus; and 2) a local factorial experiment to determine the effects of inoculation with the above fungi and the substrate disinfection method.

\section{MATERIALS AND METHODS}

\subsection{Inoculation experiments at three different locations}

The experiments were set up in greenhouses at three experimental locations: the nursery of Peyrat-le-Château located in central France, and the research centres of Champenoux in northeast France and Cabrils in northeast Spain.

Douglas fir cuttings were obtained from a total of 200 3-year-old mother plants (seed orchard 24 established at Bout, Allier, France) in February 1995. The cuttings were mixed homogeneously and cold stored at $2{ }^{\circ} \mathrm{C}$ for 4 weeks to improve rooting. After storage, the bases of the cuttings were dipped in a solution of Exuberone ${ }^{\circledR}$ (Rhone Poulenc, $4 \mathrm{~g} \mathrm{~L}^{-1}$ indole-butyric acid, IBA) for $24 \mathrm{~h}$. The substrate, consisting of a mixture of peat and vermiculite $(1: 1, \mathrm{v}: \mathrm{v})$, was disinfected with $60 \mathrm{~g} \mathrm{~L}^{-1}$ methyl bromide ( $2 \%$ chloropicrine) at a temperature over $13{ }^{\circ} \mathrm{C}$. The containers were plastic horticultural trays $(510 \times 365 \times 180$ $\mathrm{mm}$ ) at Peyrat-le Château, $\mathrm{HIKO}^{\circledR}$ plates with 40 alveoles of $90 \mathrm{cc}$ each at Champenoux, and forest-pot containers, $150 \mathrm{cc}$ each, at Cabrils. Insertion of the cuttings was done during the first week of March 1995, 2 weeks after substrate disinfection.

Laccaria bicolor (R Mre) Orton strain S-238 N was inoculated at insertion as vegetative inoculum grown in peat:vermiculite as described by Marx and Bryan [16] at the rate of 1:20 (v:v, inoculum:substrate). Sporocarps of Melanogaster ambiguus (Vitt) Tul \& Tul and Rhizopogon subareolatus Smith were collected in the Montseny range, Girona, northeast Spain, in autumn 1994. Spore inoculum of both fungi was prepared as described by Castellano et al. [6] and applied 2 months after insertion at the rate of $10^{6}$ spores per cutting as described in Parladé et al. [21].

For each location, the experimental design consisted of four replications of 40 cuttings (experimental unit) for each inoculation treatment including a control, non-inoculated treatment. The trays were distributed randomly in a greenhouse and maintained under mist irrigation during the rooting process and afterwards, under regular irrigation. Fertirrigation was started 4 months after insertion by using the N-P-K soluble fertilizer Plant Prod 20-20-20 sprayed weekly at the rate of $1.5 \mathrm{~g} \mathrm{~m}^{-2}$.

\subsection{Factorial experiment at Cabrils location}

The factorial experiment design included two factors: inoculation and the substrate disinfection method with four replications of 40 cuttings (experimental unit) for each treatment. Fungal inocula, inoculation levels and growing conditions were exactly the same as described earlier. The disinfection levels were methyl bromide applied as in the previous experiment, and steam was applied twice at $90^{\circ} \mathrm{C}$ for $1 \mathrm{~h}$ with a $24-\mathrm{h}$ period between applications.

Eight months after insertion, all the cuttings from both experiments were assessed visually for rooting (root system fully developed) and mycorrhizal colonization. Forty cuttings taken randomly from each treatment were examined for root colonization by counting at least 200 short roots per plant under a stereomicroscope. Only mycorrhizal plants were considered to determine the colonization level. Rooting and mycorrhizal colonization data were analyzed by analysis of variance (ANOVA) on the mean values per experimental unit (tray of 40 plants). 
Colonization percentages were transformed with the arc sinus function to reduce the error variance [26] before performing the ANOVA. Differences among means were detected by Tukey's test $(P \leq 0.05)$.

\section{RESULTS}

\subsection{Inoculation experiments at three different locations}

At Peyrat-le-Château and Champenoux, there were no differences in rooting due to the inoculation treatment. At Cabrils, the cuttings inoculated with $L$. bicolor and $R$. subareolatus rooted significantly better than non-inoculated cuttings. The average rooting percentage, however, was lower than in the other two locations (table I).

The cuttings inoculated with $L$. bicolor became mycorrhizal in a proportion varying from 20 to $89 \%$, depending on the location (table II). The mycorrhizal short roots rate (colonization level) among the mycorrhizal plants ranged from 40 to $59 \%$ (table III). The proportion of mycorrhizal cuttings with $R$. subareolatus varied from 31 to $88 \%$ among locations (table II). The colonization level ranged from 14 to $39 \%$ of the short roots (table III). The inoculation with $M$. ambiguus was effective only at Cabrils. Only $8 \%$ of the plants became mycorrhizal (table II) with an average of $31 \%$ of the short roots colonized (table III).

\subsection{Factorial experiment at Cabrils}

The percentage of rooted cuttings was significantly affected by both inoculation $(P=0.0006)$ and disinfection $(P=0.0000)$ factors. No significant interactions were detected between them $(P=0.7223)$. Inoculation with $L$. bicolor and $R$. subareolatus significantly increased the percentage of rooted cuttings over non-inoculated cuttings (table $I V$ ). No significant effect on rooting occurred when the cuttings were inoculated with $M$. ambiguus.

Substrate disinfection with methyl bromide significantly decreased the percentage of rooted cuttings compared to the rooting percentage obtained on steam-disinfected substrate (43 and $70 \%$, respectively). Methyl bromide application also decreased the percentage of mycorrhizal cuttings after inoculation with $L$. bicolor and $R$. subareolatus (table $V$ ).

The disinfection method did not significantly affect the colonization level of the plants for any of the inoculation treatments (table $V$ ).
Table I. Effect of four inoculation treatments on rooting percentage of Douglas fir cuttings in three European locations. Values in each column followed by the same letter are not different by Tukey's test $(P \leq 0.05)$.

\begin{tabular}{lccc}
\hline Fungal treatments & \multicolumn{3}{c}{ Location } \\
\cline { 2 - 4 } & Peyrat-le-Château & Champenoux & Cabrils \\
\hline Control & $58 \mathrm{a}$ & $67 \mathrm{a}$ & $28 \mathrm{a}$ \\
L. bicolor & $68 \mathrm{a}$ & $71 \mathrm{a}$ & $57 \mathrm{~b}$ \\
R. subareolatus & $43 \mathrm{a}$ & $66 \mathrm{a}$ & $55 \mathrm{~b}$ \\
M. ambiguus & $58 \mathrm{a}$ & $69 \mathrm{a}$ & $32 \mathrm{ab}$ \\
\hline
\end{tabular}

Table II. Percentage of mycorrhizal plants after inoculation of Douglas fir cuttings during the rooting phase with different ectomycorrhizal fungi in three European locations.

\begin{tabular}{lccc}
\hline Fungal treatments & \multicolumn{3}{c}{ Location } \\
\cline { 2 - 4 } & Peyrat-le-Château & Champenoux & Cabrils \\
\hline Control & 0 & 0 & 0 \\
L. bicolor & 89 & 20 & 38 \\
R. subareolatus & 88 & 85 & 31 \\
$M$. ambiguus & 0 & 0 & 8 \\
\hline
\end{tabular}

Table III. Mycorrhizal short root percent (colonization level) among the mycorrhizal plants on Douglas fir cuttings inoculated during the rooting phase with different ectomycorrhizal fungi in three European locations.

\begin{tabular}{|c|c|c|c|}
\hline \multirow[t]{2}{*}{ Fungal treatments } & \multicolumn{3}{|c|}{ Location } \\
\hline & Peyrat-le-Château & Champenoux & Cabrils \\
\hline Control & 0 & 0 & 0 \\
\hline L. bicolor & 40 & 40 & 59 \\
\hline R. subareolatus & 14 & 39 & 38 \\
\hline M. ambiguus & 0 & 0 & 31 \\
\hline
\end{tabular}

Table IV. Effect of inoculation on rooting of Douglas fir cuttings at Cabrils. Values followed by the same letter are not significantly different by Tukey's test $(P \leq 0.05)$.

\begin{tabular}{lc}
\hline Fungal species & \% rooting \\
\hline Control & $45 \mathrm{a}$ \\
M. ambiguus & $47 \mathrm{a}$ \\
R. subareolatus & $67 \mathrm{~b}$ \\
L. bicolor & $67 \mathrm{~b}$ \\
\hline
\end{tabular}

\section{DISCUSSION}

The substrate disinfection with methyl bromide performed at Cabrils decreased the average rooting potential 
Table V. Effect of the disinfection method on the percentage of mycorrhizal Douglas fir cuttings and on the colonization level among the mycorrhizal plants, after inoculation with different ectomycorrhizal fungi at Cabrils. For each column, values in the same fungal treatment followed by the same letter are not significantly different by Tukey's test $(P \leq 0.05)$.

\begin{tabular}{lccc}
\hline $\begin{array}{l}\text { Inoculated } \\
\text { fungus }\end{array}$ & $\begin{array}{c}\text { Disinfection } \\
\text { method }\end{array}$ & $\begin{array}{c}\% \text { mycorrhizal } \\
\text { cuttings }\end{array}$ & $\begin{array}{c}\% \text { mycorrhizal } \\
\text { colonization }(*)\end{array}$ \\
\hline L. bicolor & Methyl bromide & $38 \mathrm{a}$ & $59 \mathrm{a}$ \\
R. subareolatus & Methyl bromide & $88 \mathrm{~b}$ & $62 \mathrm{a}$ \\
& Steam & $70 \mathrm{~b}$ & $38 \mathrm{a}$ \\
M. ambiguus & Methyl bromide & $8 \mathrm{a}$ & $41 \mathrm{a}$ \\
& Steam & $12 \mathrm{a}$ & $48 \mathrm{a}$ \\
& &
\end{tabular}

$\left(^{*}\right)$ : among mycorrhizal plants

probably because of the persistence of phytotoxic residuals in the substrate. Although methyl bromide is considered a short-residual sterilant when applied properly in the soil [4], it may persist in organic or clayey soils producing phytotoxic effects [24]. Methyl bromide has been widely used in bareroot nurseries in mycorrhizal inoculation programmes to reduce competition between wild and inoculated fungi, as well as to control soil-borne root pathogens [7]. However, steam has been recommended for the disinfection of artificial growing media in container nurseries [5]. Chemicals such as chloropicrin, methyl bromide and Vapam ${ }^{\circledR}$ are also used for sterilization of growing media, but they may bind with the expanded vermiculite causing phytotoxicity even after prolonged aeration [28]. Problems caused by methyl bromide as a disinfectant were not consistent among locations although the application methodology was the same. As Molina and Trappe stated [19], a given chemical will not necessarily produce the same response in all species of fungi or hosts or in all nurseries. In any case, the use of steam can avoid the possible phytotoxicity problems of residuals connected with local growth conditions (substrate compaction, container type, temperature, humidity, etc.). In addition, methyl bromide has been listed under the Montreal Protocol on Substances that Deplete the Ozone Layer and is to be banned in the future. The use of steam as soil disinfectant has been cited in some case studies [3] as a relatively inexpensive and efficient alternative to methyl bromide.

Inoculation with $L$. bicolor and $R$. subareolatus only increased significantly the rooting performance of the cuttings produced at Cabrils. At the other two locations, the average rooting percentages were higher than those in
Cabrils and no inoculation effect was detected. The mechanism underlying the fungal ability to improve the rooting performance is unclear. It has been demonstrated that several fungi produce indole-acetic acid, (IAA) in variable amounts, which play a role in the stimulation of root branching during the mycorrhizal colonization $[8$, 25].

Inoculation with vegetative inoculum of L. bicolor at insertion was successful at the three locations. The variability observed in the colonization data is consistent with the results obtained with Douglas fir seedlings in previous inoculation experiments with the same fungal species $[11,12,14,18,20]$.

Inoculations with spores of $M$. ambiguus and $R$. subareolatus made at Cabrils resulted in root colonization percentages similar to those obtained with seedlings in previous experiments [21]. At the other two locations, only spore inoculations with $R$. subareolatus were effective. Since fungal inoculum, plant material and substrate were the same in the three locations, the failure of $M$. ambiguus in France could be due to the different environmental growth conditions (temperature, humidity, light) between France and Spain.

The methyl bromide disinfection method applied at Cabrils also lowered the percentage of mycorrhizal plants obtained after inoculation with $L$. bicolor and $R$. subareolatus. The presence of toxic residuals in the substrate could alter the fungal development after their inoculation. The lack of effect on $M$. ambiguus may be due to the delay in its development compared with that of the other two fungi. In this, and other experiments carried out with seedlings, it has been observed that this fungus takes much longer than $L$. bicolor and $R$. subareolatus to form ectomycorrhizas [21]. It can be hypothesized that spore germination takes place when the toxic effect remaining in the substrate has disappeared. For the three fungi, the mycorrhizal short root rate among the mycorrhizal plants was not affected by the disinfection method, indicating that the toxic effect on the fungi was produced before the fungal penetration into the root.

From these experimental results, it is possible to use the available inoculation techniques during the rooting phase to obtain mycorrhizal Douglas fir cuttings. Inoculation with certain ectomycorrhizal fungi improved rooting performance only at Cabrils where the rooting percentage of non-inoculated cuttings was clearly under that obtained at the other two locations. In any case, substrate treatment with steam seems to be the best disinfection method to optimize both rooting performance and short root mycorrhizal colonization. Further research is needed to test the field performance of the mycorrhizal rooted cuttings and to compare the results with those obtained with seedlings. 
Acknowledgements: Financial support for this research was provided by the European Union contract AIR 3 CT 93-1742. The authors also wish to thank A. Rodriguez, G. Vega and A. Thivolle-Cazat for their technical support on rooting techniques.

\section{REFERENCES}

[1] Alvarez I.F., Duñabeitia M., Espinel S., Hormilla S., Parladé J., Peña J.I., Pera J., Field performance of containerized Douglas fir seedlings inoculated with three hypogeous fungi, in: Azcon-Aguilar C., Barea J.M. (Eds.), Mycorrhizas in Integrated Systems from Genes to Plant Development, European Commission Report EUR 16728 EN, Brussels, Luxembourg, 1994, pp. 413-416.

[2] Alvarez I.F., Parladé J., Pera J., Espinel S., Bouchard D., Le Tacon F., Performance of bareroot Douglas fir seedlings inoculated with Laccaria bicolor S-238 five years after field outplanting, in: Azcon-Aguilar C., Barea J.M. (Eds.), Mycorrhizas in Integrated Systems from Genes to Plant Development, European Commission Report EUR 16728 EN, Brussels, Luxembourg, 1994, pp. 417-419.

[3] Banks H.J., Agricultural Production without Methyl Bromide - Four Case Studies, CSIRO Division of Entomology, CSIRO Australia, 1995.

[4] Bohmont B.L., The New Pesticide User's Guide, Reston Publishing Company Inc., Reston, VA, 1983.

[5] Castellano M.A., Molina R., Mycorrhizae, in: Landis T.D., Tinus R.W., McDonald S.E., Barnett J.P. (Eds.), The Container Tree Nursery Manual Agric. Handbook 674, Washington DC, US Department of Agriculture, Forest Service, 1989, pp. 101-167.

[6] Castellano M.A., Trappe J.M., Molina R., Inoculation of container-grown Douglas fir with basidiospores of Rhizopogon vinicolor and $R$. colossus: effects of fertility and spore application rate, Can. J. For. Res. 15 (1985) 10-13.

17] Cordell C.E., Marx D.H., Effects of nursery cultural practices on management of specific ectomycorrhizae on bareroot tree seedlings, in: Pfleger F.L., Linderman R.G. (Eds.), Mycorrhizae and Plant Health, APS Press, St. Paul, MN, 1994, pp. 133-151.

[8] Gay G., Gea L., Rôle de l'auxine fongique dans la formation des ectomycorhizes, Acta Bot. Gallica 141 (1994) $491-496$.

[9] Généré B., Évaluation en jeune plantation de deux types de plants de douglas mycorhizés artificiellement par Laccaria laccata S 238 N, Ann. Sci. For. 52 (1995) 375-384.

[10] Généré B., Le Tacon F., Amirault J.M., Bouchard D., La mycorhization contrôlée de boutures d'épicéa commun en pépinière, Rev. For. Fr. 46 (1994) 49-58.

[11] Hung L.L., Molina R., Use of the ectomycorrhizal fungus Laccaria laccata in forestry. III. Effects of commercially produced inoculum on container-grown Douglas fir and ponderosa pine seedlings, Can. J. For. Res. 16 (1986) 802-806.

[12] Hung L.L., Trappe J.M., Ectomycorrhizal inoculation of Douglas fir transplanted container seedlings with commercially produced inoculum, New Forests 1 (1987) 141-152.

[13] Le Tacon F., Bouchard D., Effects of different ectomycorrhizal fungi on growth of larch, Douglas fir, Scots pine and Norway spruce seedlings in fumigated nursery soil, Acta Oecol. Oecol. Appl. 7 (4) (1986) 389-402.

[14] Le Tacon F., Garbaye J., Bouchard D., Chevalier G., Olivier J.M., Guimberteau J., Poitou N., Frochot N., Field results from ectomycorrhizal inoculation in France, in: Lalonde M., Piché Y. (Eds.), Proceedings of the Canadian Workshop on Mycorrhizae in Forestry, 1-4 May 1988, Centre de recherche en biologie forestière, Faculté de foresterie et de géodésie, Université Laval, Sainte-Foy, Québec, 1988.

[15] Le Tacon F., Alvarez I.F., Bouchard D., Henrion B., Jackson R.M., Luff S., Parladé J., Pera J., Stenström E., Villeneuve N., Walker C., Variations in field response of forest trees to nursery ectomycorrhizal inoculation in Europe, in: Read D.J., Lewis D.H., Fitter A.H., Alexander I.J. (Eds.), Mycorrhizas in Ecosystems, CAB, Wallingford, 1992, pp. $119-134$

[16] Marx D.H., Bryan W.C., Growth and ectomycorrhizal development of loblolly pine seedlings in fumigated soil infested with the fungal symbiont Pisolithus tinctorius, For. Sci. 21 (1975) 245-254.

[17] Matthews J.D., The Role of North-West American Trees in Western Europe, H.R. McMillan Lectureship in Forestry, Univ. BC, Vancouver, BC, 1983.

[18] Molina R., Use of the ectomycorrhizal fungus Laccaria laccata in forestry. 1. Consistency between isolates in effective colonization of containerized conifer seedlings, Can. J. For. Res. 12 (1982) 469-473.

[19] Molina R., Trappe J.M., Mycorrhiza management in bareroot nurseries, in: Duryea M.L., Landis T.D. (Eds.), Forestry Nursery Manual: Production of Bareroot Seedlings, Martinus Nijhoff/Dr W. Junk Publishers, the Hague, 1984, pp. 211-223.

[20] Parladé J., Técnicas de inoculación de abeto de Douglas [Pseudotsuga menziesii (Mirb.) Franco] con hongos ectomicorrícicos y su aplicación en reforestación, tesis doctoral, Universidad Autónoma de Barcelona, Spain, 1992.

[21] Parladé J., Pera J., Alvarez I.F., Inoculation of containerized Pseudotsuga menziesii and Pinus pinaster seedlings with spores of five species of ectomycorrhizal fungi, Mycorrhiza 6 (1996) 237-245.

[22] Ritchie G.A., The commercial use of conifer rooted cuttings in forestry: a world overview, New Forests 5 (1992) $247-275$.

[23] Ritchie G.A., Tanaka Y., Meade R., Duke S.D., Field survival and early growth of Douglas fir rooted cuttings: relationship to stem diameter and root system quality, For. Ecol. Manage. 60 (1993) 237-256. 
[24] Shurtleff M.C., How to Control Plant Diseases, Iowa State University Press, Ames, IA, 1966.

[25] Slankis V., Hormonal relationship in mycorrhiza, in: Marks G.C., Kozlowski T.T. (Eds.), Ectomycorrhizae - Their Ecology and Physiology, Academic Press, New York, London, 1973, pp. 231-298.

[26] Snedecor G.W., Cochran W.G., Statistical Methods, Iowa State University Press, Ames, IA, 1980.
[27] Stenström E., Ek M., Field growth of Pinus sylvestris following nursery inoculation with mycorrhizal fungi, Can. J. For. Res. 20 (1990) 914-918.

[28] Tinus R.W., McDonald S.E., How to Grow Tree Seedlings in Containers in Greenhouses, USDA Fr. Serv. Gen. Tech. Rep. RM-60, Rocky Mt. For. and Range Exp. Stn., For. Serv., US Dept. Agric., Fort Collins, CO 80526, 1979. 